\title{
The Role of Ethnic Retailing in Retrofitting Suburbia: Case Studies from Toronto, Canada
}

\section{Zhixi Cecilia Zhuang \& Amanda Xiaoxuan Chen}

To cite this article: Zhixi Cecilia Zhuang \& Amanda Xiaoxuan Chen (2016): The role of ethnic retailing in retrofitting suburbia: case studies from Toronto, Canada, Journal of Urbanism: International Research on Placemaking and Urban Sustainability, DOI: $10.1080 / 17549175.2016 .1254671$

To link to this article: http://dx.doi.org/10.1080/17549175.2016.1254671

The Version of Record of this manuscript has been published and is available in Journal of Urbanism: International Research on Placemaking and Urban Sustainability, published online November 14, 2016, http://www.tandfonline.com/ DOI: 10.1080/17549175.2016.1254671.

\begin{abstract}
:
Today's immigrants to Canada are increasingly and directly settling into suburban areas of major cities; a trend that has resulted in new retail opportunities: suburban ethnic shopping centres are a growing phenomenon in areas with major immigrant settlement. This paper discusses the development and retrofitting processes of three suburban Chinese shopping malls in the Toronto area. The paper explores how these malls successfully regenerated areas once affected by business decline and how they can act as a catalyst to develop a new urban form that makes the suburban landscape less uniform and more sustainable. Various perspectives from key players involved in ethnic retail activities and developments were collected, including surveys with entrepreneurs and shoppers, and semi-structured interviews with city councillors, city planners, developers, and an architect. The paper suggests that municipalities could invest in established ethnic retail places as an innovative means of "retrofitting suburbia."
\end{abstract}

\section{Keywords:}


Ethnic Retailing, Retrofitting Suburbia, Chinese Malls, Chinese Ethnoburbs, Toronto

\section{Introduction}

Today's immigrants to Canada are increasingly and directly settling into suburban areas of major cities. This trend has brought with it new retail opportunities: suburban ethnic retail locations like strip malls and shopping centres are an increasing phenomenon in areas with major immigrant settlement. The largest proportion of immigrants to Canada is currently attracted to the Greater Toronto Area (GTA), and this region has the most prominent ethnic retailing, especially Chinese shopping centres.

Suburban shopping malls across North America are in a state of decline. Parlette and Cowen noted that "“Dead malls' are now a staple of North American (sub)urban landscapes" $(2011,794)$. In stark contrast, most of the Chinese malls in the GTA are thriving. These malls serve not only as shopping destinations, but also as important community spaces by providing dining, entertainment, and personal, business, and community services. The malls' presence and changes over the years contribute to the retrofitting of existing suburban neighbourhoods. Many Chinese malls feature innovative and unconventional retail forms (e.g., condominium shopping malls), making and marking a unique suburban landscape. Some of these Chinese shopping malls are currently proposing mega-scale expansion or redevelopment in an attempt to further retrofit the existing shopping district.

The dynamics of suburban ethnic retailing generate significant (and sometimes unwelcome) changes to the existing community, which present both challenges and opportunities for municipalities. Previous studies have reported how ethnic retailing has challenged the conventional suburban planning norms through controversies relating to land-use, built form, parking capacity, economic development, and community-building (Zhuang 2013; Harwood 2005; Preston and Lo 2000; Qadeer 1997). Although "retrofitting suburbia" has emerged as a hot topic in the planning domain and one of the top items on municipal agendas (Dunham-Jones and Williamson 2011; Lukez 2007; Talen 2010, 2011, 2015; Williamson 2013), insufficient attention 
has been paid to suburban ethnic retailing and its potential contributions to the revitalization of existing neighbourhoods. This paucity of research means that municipal public policymakers remain relatively uninformed about these issues.

It is important to identify the key players involved in the development of suburban ethnic retailing, and to clarify how these retail places can contribute to community-building and suburban retrofitting. This information can inform municipalities about how they can better accommodate the growing immigrant population, facilitate their retail activities, and, importantly, identify strategies that support suburban retrofitting.

In this paper, we discuss a two-step development and retrofitting process of three suburban Chinese shopping malls (Pacific Mall, Market Village, and Splendid China Tower), which border two major immigrant-receiving municipalities in the GTA: the City of Markham and the City of Toronto (Figure 1). These Chinese malls were initially developed by readapting the existing retail spaces and they are currently slated for redevelopment. Specifically, we address the following three research questions: How has suburban ethnic retailing evolved over time and played a role in retrofitting the existing neighbourhood? What are the redevelopment approaches that would better meet current retrofitting principles? Who are the key players and what are their roles in the retail retrofitting process? Based on statistical data as well as interviews with key informants and surveys of merchants and shoppers, we trace the initial stage of development of these ethnic malls back to the 1980s and explore how they successfully regenerated areas once affected by business decline. We also explore their future redevelopment plans, and how malls can act as a catalyst to regenerate an area and to develop a new urban form that can make suburban landscape more sustainable. 


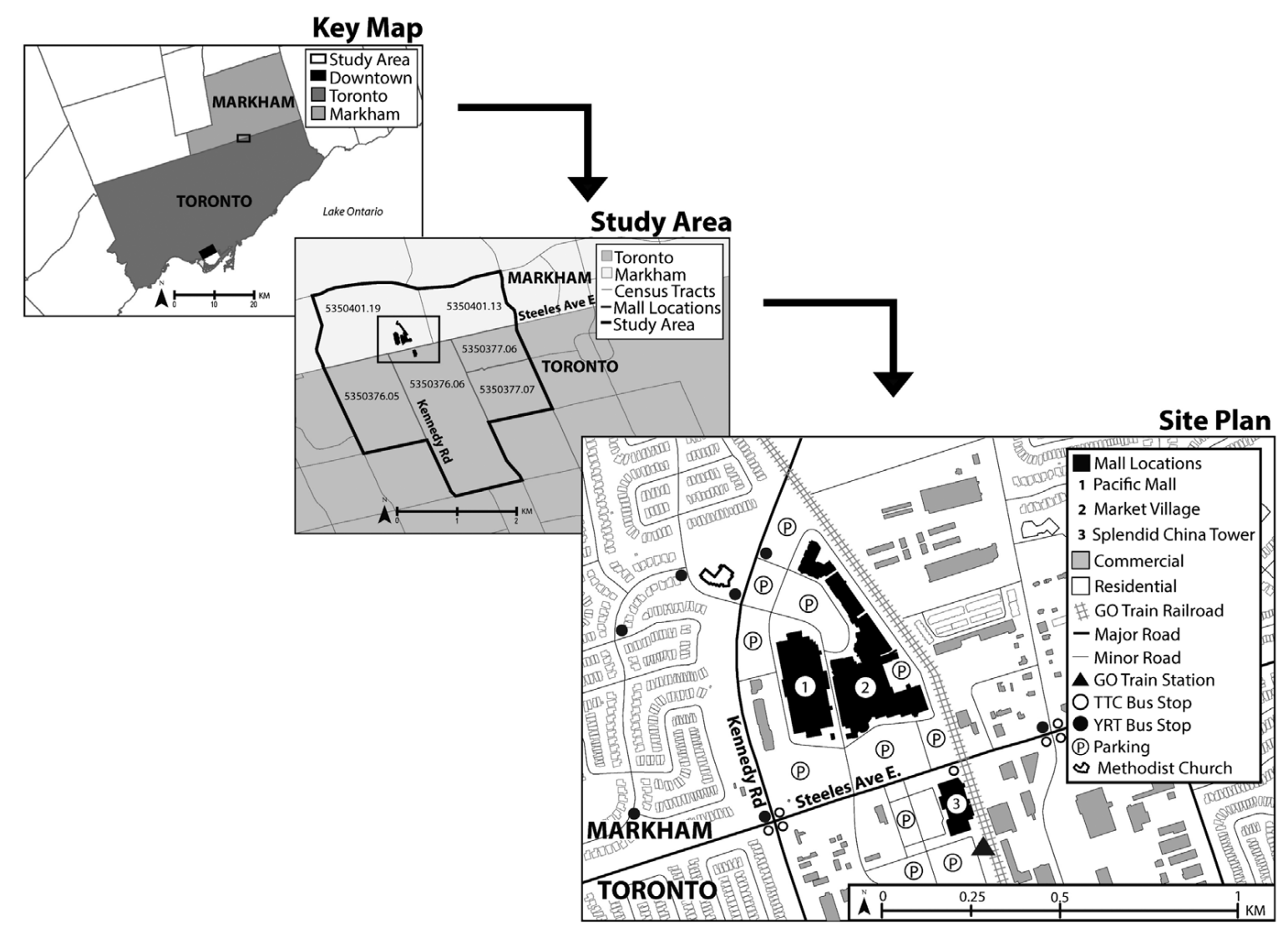

Figure 1. Locations of the three Chinese malls (Map produced by Fei Yeung Ivan Cheung).

\section{Chinese Ethnoburbs, Ethnic Retail Development, and Retrofitting Suburbia}

Contemporary suburban immigrant settlement is either in a dispersed pattern or concentrated in ethnic clusters or "ethnoburbs." According to Li (1998b, 504), ethnoburbs are "clusters of residential areas and business districts" that are multiethnic and generally have one ethnic minority group in "a significant concentration" but not necessarily a numerical majority. Empirical research has revealed that residential concentration or segregation of immigrant communities is generally not the effect of social exclusion. Rather, it is a voluntary process, and settlement patterns are shaped by local housing markets, public policy, the degree of institutional completeness of an ethnic group, and their location preference and economic mobility (Borjas 1997; Li 2006; Qadeer 2003). ${ }^{\mathrm{i}}$

The formation of Chinese ethnoburbs in metropolitan areas of major immigrant settlement is a typical example of how today's immigrants are bypassing traditional ports of entry in the inner city and directly settling in suburban areas. Some scholars have already 
focused on notable Chinese ethnoburbs, such as the San Gabriel Valley near Los Angeles, Richmond Hill and Markham in the Greater Toronto Area, Richmond in the Greater Vancouver Area, Auckland in New Zealand, Hurstville in suburban Sydney, and Northbridge in Perth (Collins 2015; Edgington et al. 2006; Fong 1994; Lai 2000; Li 1998a, 1998b, 2005, 2009, Wang and Zhong 2013; Xue et al. 2012; Zhou 2009, 2013). In some cases, these new Chinese suburbs have been referred to as the "new Chinatown" (Lai 2000; Luk 2005) and "suburban Chinatown" (Fong 1994). But in fact, these new suburban Chinese communities "are NOT Chinatowns nor traditional ethnic enclaves" (Li 2005, 38), because of "underlying dynamics, community and economic structures, socioeconomic profiles of residents and neighborhoods" (Li 2005, 32). Zhou's (2013) study of new Chinese urban enclaves and ethnoburbs in New York and Los Angeles revealed they differ from traditional Chinatowns and typical suburban American communities, because new Chinese communities have better global connections and their transnational ties to the homelands help them incorporate into the host society.

As urban ethnic enclaves like Chinatowns have revitalized declining urban neighbourhoods, suburban ethnic businesses contribute significantly to the transformations of many suburban neighbourhoods (Li 2005). Ethnoburbs promote a sense of place by providing ethnic-oriented products and services and community spaces for social, cultural, and political activities. For example, in an examination of Vietnamese retail landscape and place-making practices in Northern Virginia, Wood $(1997,2006)$ found that Vietnamese businesses readapted former retail facilities and created Vietnamese retail districts featuring retail strips and shopping plazas to serve the needs of a dispersed Vietnamese-American residential population. Over time, these retail districts have transformed the area into a vital community hub for Vietnamese Americans. Wood also found that although these Vietnamese retail businesses were highly visible to Asians, non-Vietnamese outsiders were not aware of the ethnic landscape and its social, cultural, and political meanings, nor of the contribution of Vietnamese Americans to suburban place-making.

Zhou (2013) focused on Flushing in Queens, Sunset Park in Brooklyn, and Monterey Park in Lost Angeles, exploring how these multiethnic enclaves with strong Chinese 
characteristics were formed and how they transformed suburbia with unprecedented settlement and ethnic succession patterns. Zhou concluded that "Chinese immigrants of diverse origins and socioeconomic backgrounds [have] negotiated their way into American metropolises and suburbia" (359), and that because of the multiethnic nature of ethnoburbs, diversity at the local level "has made intraethnic and interethnic relations key community issues" (381). Lung-Amam (2015a, 2015b) focused on Asian malls in Silicon Valley, exploring how they developed over four decades, mainly serving the needs of immigrants from China, Hong Kong, Taiwan, Vietnam, and the Philippines, and reflecting Asian Americans' sense of community and place. Similar to the findings of Wood $(1997,2006)$ and Zhou (2013), Lung-Amam concluded that these Asian malls embody meanings associated with Asian Americans' social and cultural life, and function as community hubs and important public meeting spaces despite their private ownership.

Notwithstanding these major studies of ethnoburbs and ethnic retailing, few scholars have explored how the resulting suburban transformations affect - and could possibly benefit - the larger project of retrofitting suburbia. Retrofitting suburbia is a movement and planning practice that calls for the repair of unsustainable suburban areas by transforming suburbs into more walkable, diverse, mixed-use, and transit- and public-oriented places. In their influential book Retrofitting Suburbia: Urban Design Solutions for Redesigning Suburbs, Dunham-Jones and Williamson defined 'retrofit' as to "extend beyond the notions of rehabilitation or adaptive reuse to encompass the idea of systemic, long-lasting, transformative change" (2011, xxviii). With regard to retrofitting suburbia, they advocated for three principal retrofitting strategies: reinhabitation, redevelopment, and regreening. Based on extensive project examples, the authors presented a wide range of ways that urban designers can retrofit the built environment, including adaptive reuse, wetland-ecology restoration, zoning-code revision, street-type and streetscape redesign, intensified and diversified housing supply, high quality architecture, and improved walkability, connectivity, and adaptability.

It is important to note that not every suburban place has the potential to be retrofitted. Talen $(2010,35)$ identified five steps for choosing potential sites and planning strategically: locating structural potential (e.g., commercial intersections, good street connectivity, shorter blocks); finding pockets of density and diversity; locating nodes occupied by buildings; selecting 
strategic areas that have a few assets to build on; and beginning implementation (e.g., stimulating investment in targeted locations, changing zoning codes, investing in public space, providing incentives for private developers). Talen defined an urban form as sustainable when it is "walkable, compact, and mixed use — or, accessible, connected, dense, diverse, and nodal" $(2011,960)$. She advocated for using these principles to retrofit urban sprawl and to evaluate and reproduce urban dynamics in unsustainable suburban places. Additionally, fixing sprawl is never easy and will be a long and difficult process, because of the social, physical, financial, and political challenges to effective retrofitting (Talen 2015).

Although the aforementioned retrofitting strategies did not specifically focus on ethnoburbs, Dunham-Jones and Williamson (2011) acknowledged the role of immigrants in transforming the social and economic landscapes of existing suburban communities. They concluded that immigration has become one of the key market indicators that support suburban retrofitting initiatives. For example, housing choices and designs have changed to accommodate the influx of immigrants, who tend to have larger families. These larger immigrant households contribute to increased population density and retrofit suburban communities by diversifying local social, economic, and cultural practices. Another example demonstrated how the existing road infrastructure and shopping strips were urbanized to cater to the needs of the immigrant population, thus retrofitting the entire highway corridor. The authors also presented a radical retrofitting proposal that aimed to build an Asian-oriented retail complex with ten 25 -storey condo towers to replace existing near-dead shopping malls. It did not, however, provide any clear indications about how this kind of high-rise epicentre for an upscale Asian community could be better integrated with the existing neighbourhoods, let alone serve the other important retrofitting goals of walkability, connectivity, and a human-scaled public realm. Despite the limited number of empirical studies, one major conclusion is that "Public investment is needed to further retrofit these [immigrant] places into healthier physical environments - with sidewalks, playgrounds, and transit — but the challenge is to do so without gentrifying a culturally rich community and erasing a needed source of low-income housing" $(2011,32)$.

Williamson (2013) presented some of the best retrofitting projects from the 2010 Build a Better Burb design competition. Given the rise of immigrant gateway suburbs in the United 
States, immigrants will be key drivers in retrofitting schemes. One of the many design challenges and priorities was to connect people of various ethno-cultural backgrounds and promote multicultural social interaction in the public realm. Such retrofitting strategies can also be applied to other types of suburbs as well as ethnoburbs: quality public spaces can help promote social interaction among diverse groups.

In summary, the changes to suburbia resulting from ethnoburbs can support the desired outcomes of the retrofitting movement (Dunham-Jones and Williamson 2011). These ethnic places readapt, transform, and reshape suburban landscapes, creating a sense of community and place. Therefore, it is vital to consider the needs of suburban immigrant communities in retrofitting schemes. However, insufficient research has focused on the potential alignment between ethnoburbia and retrofitting. For example, research on suburban Chinese retailing within a Canadian context tends to focus on general retail development patterns and structures, and associated policy factors and planning implications (Zhuang 2013; Lai 2000, 2001; Preston and Lo 2000; Qadeer 1998; Wang 1999; Wang and Zhong 2013). Few scholars have conducted in-depth empirical studies of how Chinese shopping centres evolve and create community life, and thereby affect the existing neighbourhoods. Little is known about the major players involved in their production or the mechanisms involved in their development and transformation. With the increasing focus on retrofitting suburbia in the planning literature and practice, it is important to clarify these aspects of the ethnic retail phenomenon to inform long-term planning and decision-making.

\section{Methods}

The three malls chosen for this investigation are located in a suburban area bordering the City of Toronto and the City of Markham (Figure 1). The area has a predominantly Chinese population that is much larger than the city average in both Toronto and Markham: $73.4 \%$ by home language, $74.2 \%$ by ethnic origin and by visible minority population (Table 1 ) (Statistics Canada 2011). ii 
Table 1: Chinese Population by Various Census Indicators in the Study Area, the City of Toronto, and the City of Markham

Source: Statistics Canada 2011

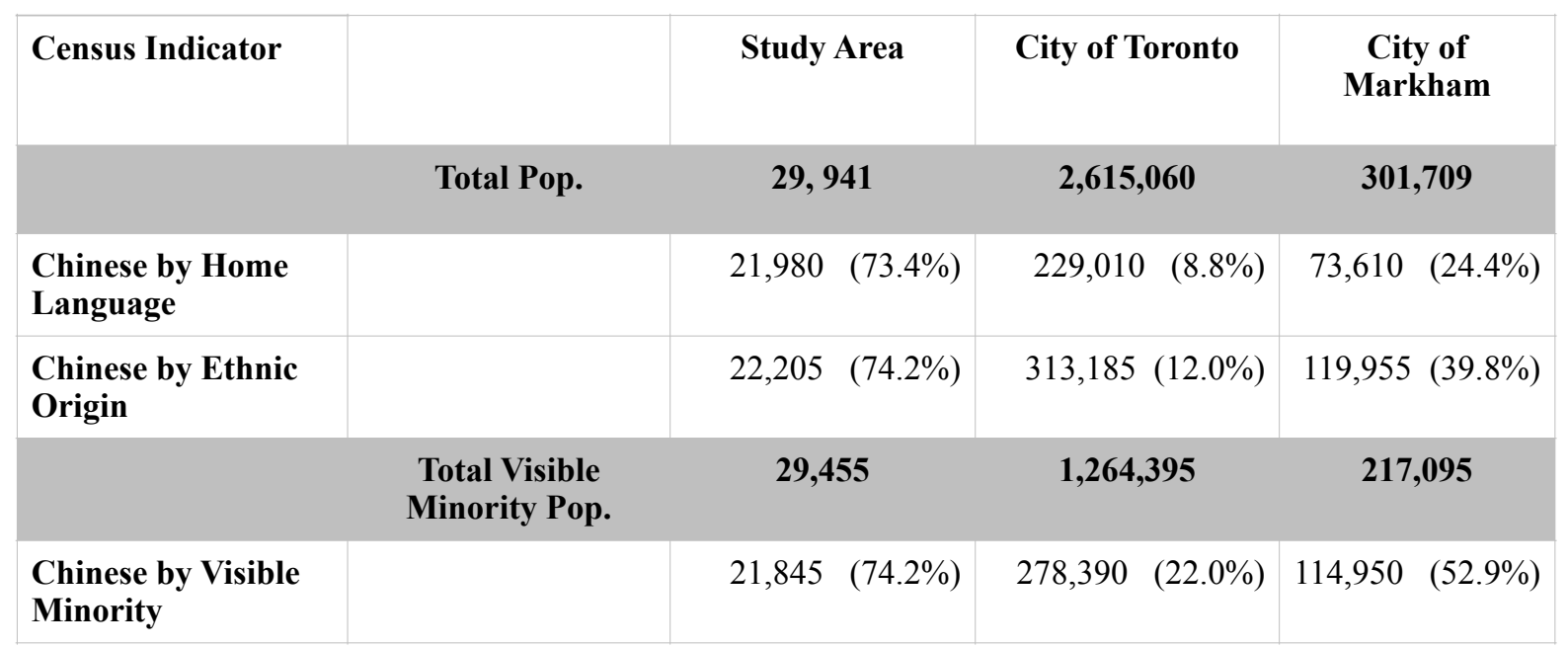

Table 2: Profile of Participants in the Three Shopping Malls

\begin{tabular}{|l|c|c|c|c|}
\hline Participants & Market Village & Pacific Mall & Splendid China Tower & Total \\
\hline $\begin{array}{l}\text { Business Owners }+ \\
\text { Employees }\end{array}$ & $12+28$ & $37+41$ & $22+14$ & $\mathbf{1 5 4}$ \\
\hline Shoppers & 15 & 34 & N/A & 49 \\
\hline Professionals & \multicolumn{2}{|r|}{2 city councillors, 3 planners, 2 developers, 1 architect } & $\mathbf{8}$ \\
\hline
\end{tabular}

Our study concerns the development of these three Chinese malls and their roles in retrofitting the study area, which is comprised of adjacent neighbourhoods containing six census tracts (Figure 1). We conducted our research in 2011 and 2012 by using multiple methods of data collection, including primary data from surveys and semi-structured interviews, secondary documents about the study area, neighbourhood demographics, mall business profiles, and site observations of social interactions, business activities, and physical layouts. We first conducted a pilot study in an adjacent Chinese shopping district, the CityWalk Plaza, by distributing a survey to nearly 30 businesses. We received 10 completed surveys, allowing us to make minor modifications to the questions. 
We collected surveys of 154 business owners/operators and 49 shoppers from the three malls, and eight semi-structured interviews with councillors, city planners, developers, and an architect (Table 2). We distributed the business surveys, which were in English and traditional and simplified Chinese, to every third store, and asked owners or operators to complete the survey on their own. We collected most of the completed surveys on the same day, and picked up the rest on a later date. Merchants were asked about their business practices, location preferences, and their views about the current shopping malls and their future redevelopments. Shoppers were randomly intercepted in Market Village and Pacific Mall within the span of one hour, as required by the management offices. Our intercept survey request was declined by Splendid China Tower's management office. Shoppers were asked about their visiting frequency, the purpose of their trips to the malls, and their opinions about the future development of the malls. The authors and the Research Assistant all speak English, Mandarin, and Cantonese fluently. These merchant and shopper surveys, along with extensive field observations at different days and different times, helped us to understand how businesses function in the malls and the users' perspectives. We used email to recruit city officials, developers, and an architect who are involved in the redevelopment process or have the knowledge to provide contextual information. Then we conducted hour-long, face-to-face interviews with them. These professionals were asked about their involvement in the redevelopment process and how they perceived the role of the redevelopment plans in retrofitting the area.

We also used the annual business survey conducted by the Centre for the Study of Commercial Activity (CSCA) at Ryerson University, consulting the data from 2000 to 2010 to determine business composition and vacancy rates at the three shopping malls.

\section{Chinese Ethnoburbs and Chinese Shopping Malls in the GTA}

The settlement of Chinese immigrants in inner and outer suburbs of the GTA, such as Scarborough, North York, Markham, Mississauga, and Richmond Hill, has been noted since the 1990s (Lo and Wang 1997; Lo 2006). A longitudinal analysis of Canadian census data from 2001 to 2006 (Qadeer et al. 2010) revealed that the suburban Chinese concentration has been 
expanding, and the authors noted that these "ethnic concentrations have been transformed into enclaves with the emergence of religious institutions, businesses and community services with a particular ethnic provenance" (325). Wang and Zhong (2013) reported that "in 2006, there were 35 census tracts and 11 neighbourhoods with 50 percent or more of their populations being Chinese ... [and] most of the Chinese concentrations were in Scarborough and Markham" (17). They also found that 57 of the 66 Chinese shopping malls that have emerged in the GTA during the past two decades were developed in ethnoburbs.

Chinese shopping malls are by far the most prominent example of suburban ethnic retailing in Canada. No other ethnic group has developed such shopping centres, despite the sizeable populations of some, such as Italians and South Asians (Qadeer 1998; Wang and Zhong 2013). The rise of Chinese shopping malls can be attributed to access to capital as well as strong market demand and supply. The Chinese population in the GTA is over half a million, and it has built a strong community with a high degree of institutional completeness in which Chinese entrepreneurs and consumers have built a sustainable, self-sufficient economy (Qadeer 1997; Wang 1999). A Chinese shopping mall typically differs from a mainstream shopping centre in the following ways: it has a concentration of businesses operated by, and oriented toward, Asians, and a large variety of retail, business, and personal services. Its anchoring businesses are not department stores, such as the Bay and Sears, but rather restaurants or grocery stores. Also, the stores are smaller and have varying operating hours, and there is no control of the tenant mix (Lai 2000; Preston and Lo 2000; Qadeer 1998; Wang 1999). The Chinese shopping centre's most innovative characteristic is its condominium-style retail-occupancy system (Wang 1999). Unlike the leasehold system used in conventional shopping centres, business units in a Chinese condominium mall may be purchased or rented. This ownership system was imported from Hong Kong and mainly targets Chinese individuals interested in purchasing properties for residential or business purposes; the possibility of investment in mall properties offered immigration opportunities under Canada's business-class immigrant program (Wang 1999). iii

A visual survey of Chinese malls in the GTA conducted by the authors reveals that the older malls in Scarborough, developed in the 1980s, have experienced business decline and ethnic succession. They have a moderate vacancy rate and are becoming multiethnic by 
including South Asian, Korean, Vietnamese, Filipino, and other mainstream non-ethnic businesses. Other researchers found similar succession trends in other Chinese enclaves or ethnoburbs, such as those in Flushing, Sunset Park, Mississauga, and Toronto (Lo 2006; Luk and Phan 2005; Zhou 2013). However, unlike the older Chinese malls in Scarborough, the three malls focused on in the current study are predominantly owned and operated by Chinese and the area is considered the most famous and successful Chinese business district in the GTA (Lo 2006).

\section{The Readapted Retail Landscape since the 1990s}

Over the past two decades, the development of the Pacific Mall, Market Village, and Splendid China Tower illustrates how Chinese businesses revitalized a once-declining area and readapted the retail landscape by creating a thriving, Asian-oriented business hub and providing community spaces. The suburban landscape was transformed significantly, with long-lasting social, economic, and physical effects. It is important to investigate the transformation and readaptation of the retail landscape to answer the following research question: how has suburban ethnic retailing evolved over time and played a role in retrofitting the existing neighbourhood?

Most of the land in the study area was covered by farm fields until the late 1970s when new subdivisions were developed (Figure 2). In 1983, the first commercial complex built in the area was Cullen Country Barns, a once-popular Markham tourist destination featuring countrythemed giftware, garden supplies, and a petting zoo (Figures 2 and 3). Market Village opened in 1990, and was not at first a Chinese mall. To reflect and reinforce Markham's rural traditions, the mall's nine buildings were constructed with a consistent old-town architectural style and linked by an outdoor shopping street (Figures 2, 4, and 5) (Relph 2014). When Canadian Tire, a mainstream big-box retailer, opened across Steeles Avenue in 1991, the site took shape with these three major commercial buildings serving a mainstream market and reflecting a nostalgic, small-town landscape (Figure 2). 
Figure 2: Aerial photos of the site from 1977 to 1991 Source: City of Toronto Archives

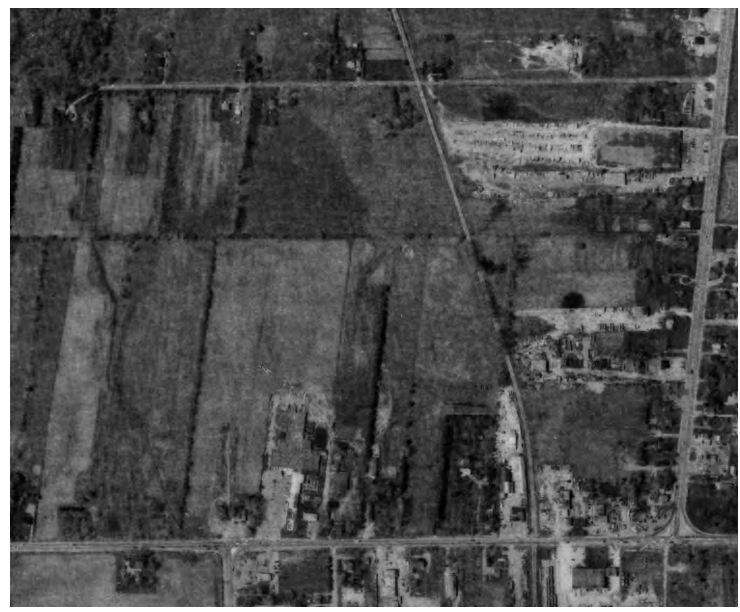

1977: site covered by farm field

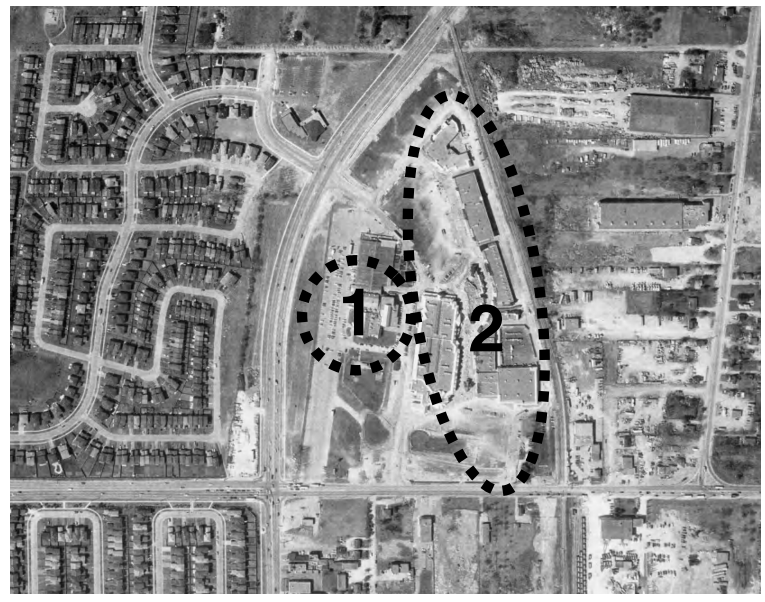

1989: Market Village (2) under construction

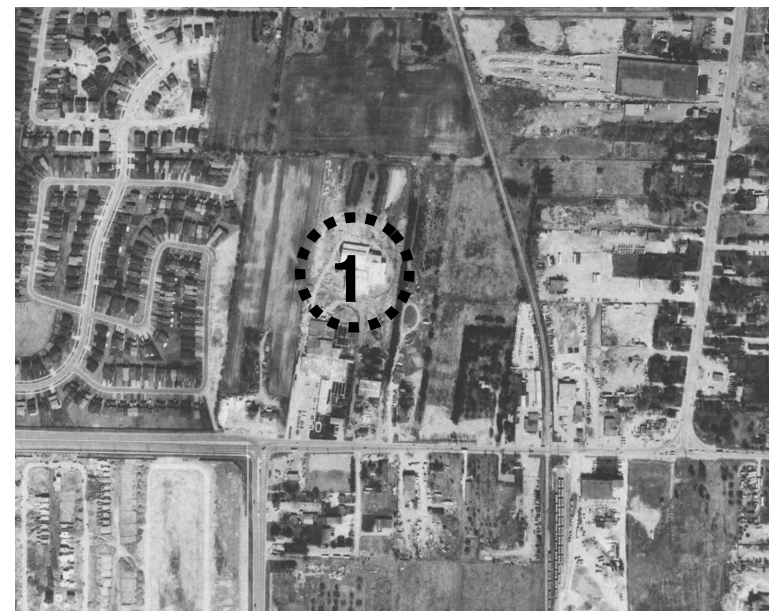

1983: Cullen Country Barns (1) first built

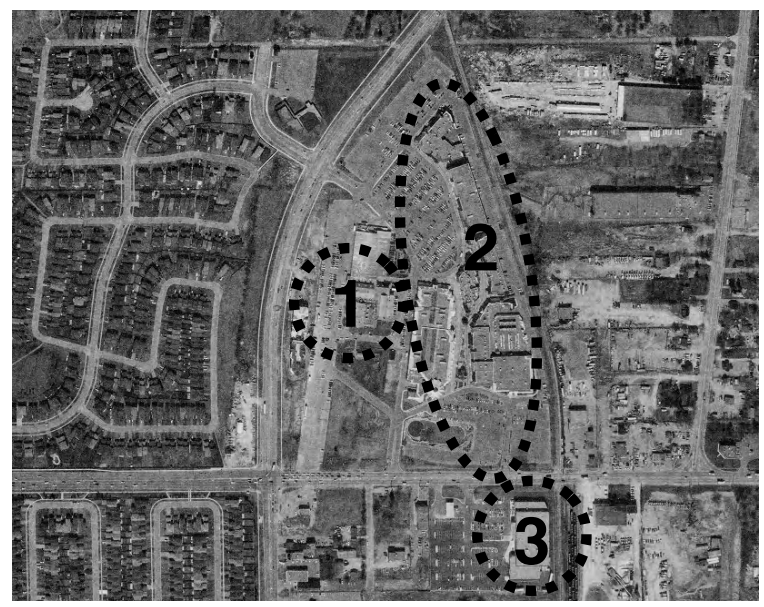

1991: Canadian Tire (3) opened across the street 
Figure 3: Cullen Country Barns in 1992. Image with permission from Edward Relph at http://www.torontotransforms.com

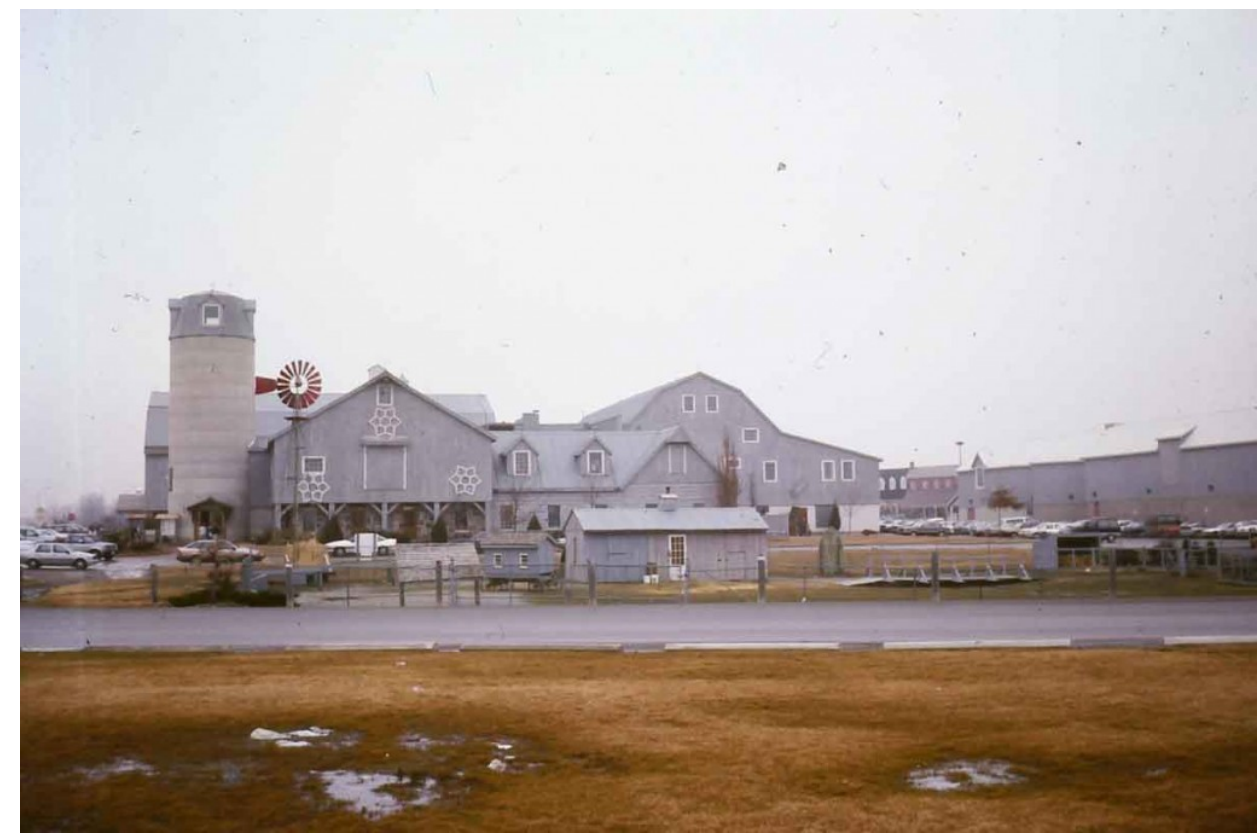

Figure 4: Market Village being converted from an outdoor shopping centre to an indoor shopping mall.

Image with permission from Edward Relph at

http://www.torontotransforms.com

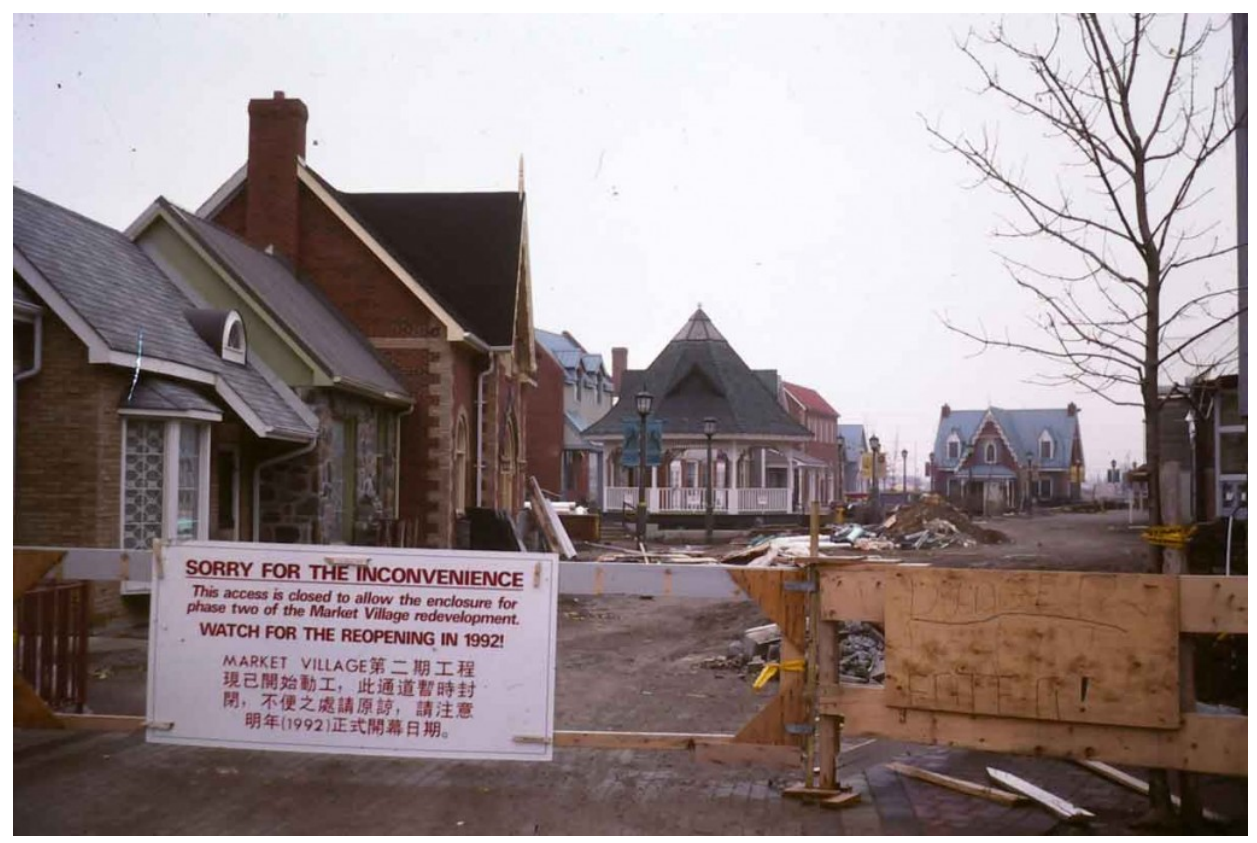




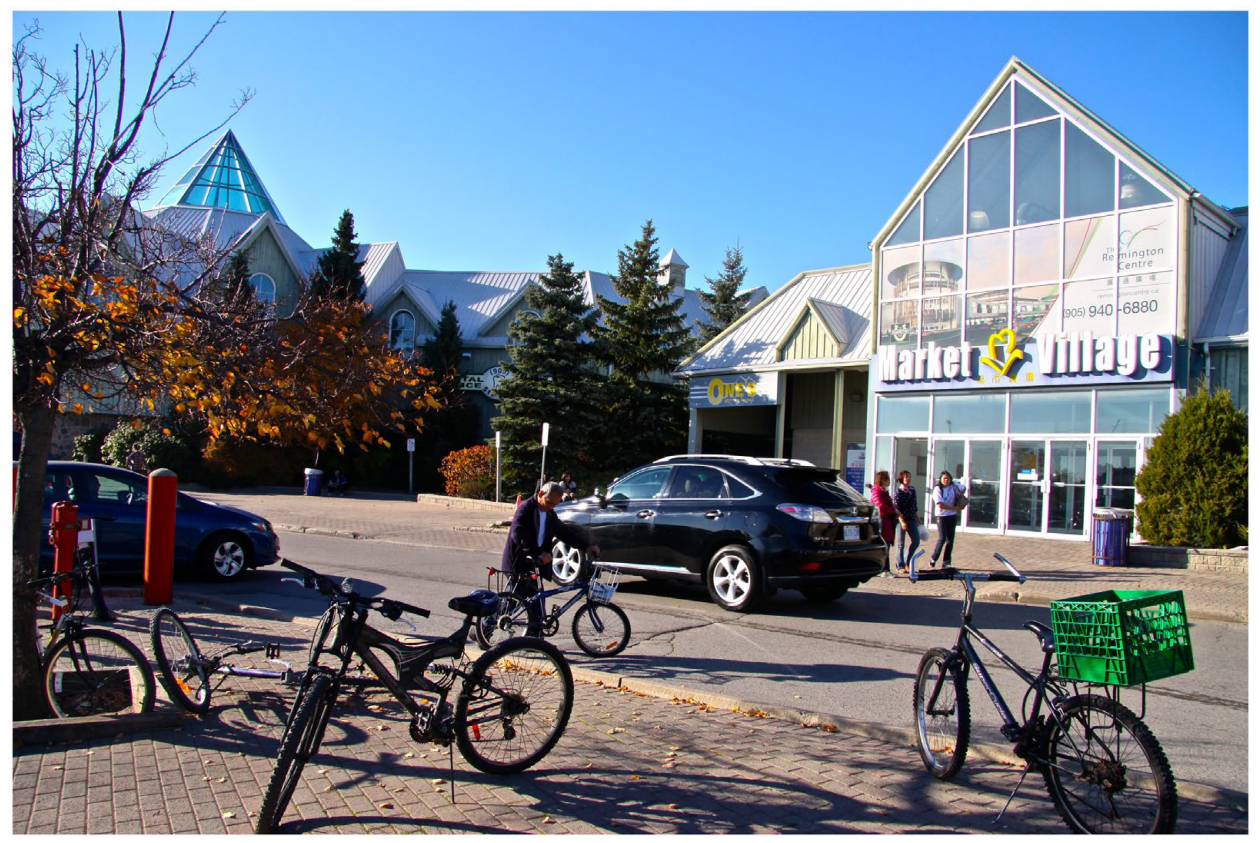

Figure 5. New entrance to Market Village after its conversion into an indoor shopping mall.

However, most of the businesses in Market Village failed in the early 1990s because the country theme was no longer an attraction (Heaslip 2011). Given the influx of Asian immigrants to Markham, many Chinese-owned/operated businesses seized the opportunity, renting commercial units in Market Village to meet the changing demographics of the area. Interviewed on his experience, a city councillor who represented the area for over two decades recalled:

When Market Village started, they were not there for Chinese ... But somehow it didn’t work out. And Chinese merchants came in, Chinese grocers came in. And people see that as a good thing and people don't have to go downtown

[Chinatown] to do groceries. And then it just expanded there. And next thing you know, they put a Chinese theatre. All of a sudden, Chinese restaurants, you know, so you don't dictate that.

Market Village was converted into an indoor retail facility in 1995 (Figure 5). It was readapted predominantly by Chinese businesses serving a growing Asian-oriented market. Meanwhile, due to business decline, Cullen Country Barns closed in 1994 and was demolished, making way for a retail replacement, later known as the Pacific Mall (Figure 6). Unlike the leasehold structure in Market Village, condominium ownership was introduced in the preconstruction sale of Pacific Mall store units to draw investors from Hong Kong and Canada. 
These strata-titled units were smaller (averaging 200 square feet) than those in a conventional shopping mall, resulting in more intense commercial activity, more demand for parking, and more traffic. As the interviewed Markham councillor and planner recalled, there were residents within the local community who felt uncomfortable about this unconventional retail form and its targeted ethnic market, but "they either adapted or moved." An economic impact assessment conducted by Markham's Economic Development Office perceived it "as an economic engine for the area" (Zhuang 2013, 107). Pacific Mall is now considered the flagship Chinese condominium mall in Canada, and has drawn considerable attention from media and academics because of its business success, the controversies associated with its land uses (e.g., parking, traffic), and its ethnic business concentration (see Zhuang 2013; Chen 2005; Gillmor 1998; Wong 2007). Despite tensions that have arisen about land use associated with this unprecedented condominium retail form, other developers followed suit to maximize the potential of a growing ethnic market. In 2007, when Canadian Tire closed, developers converted the vacant building into another condominium Chinese mall, the Splendid China Tower (Figure 7).

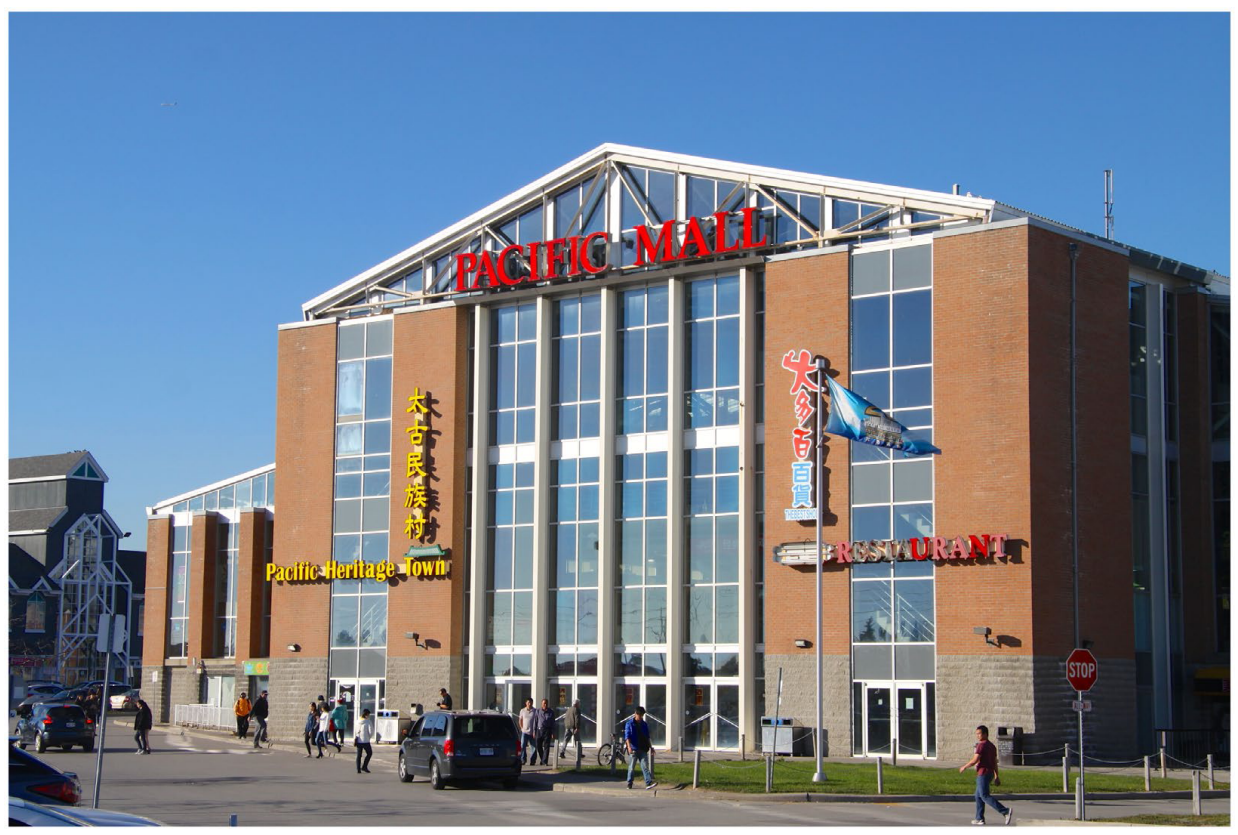

Figure 6. The exterior of the Pacific Mall does not distinguish itself from other mainstream shopping centres except for its Chinese signage. 


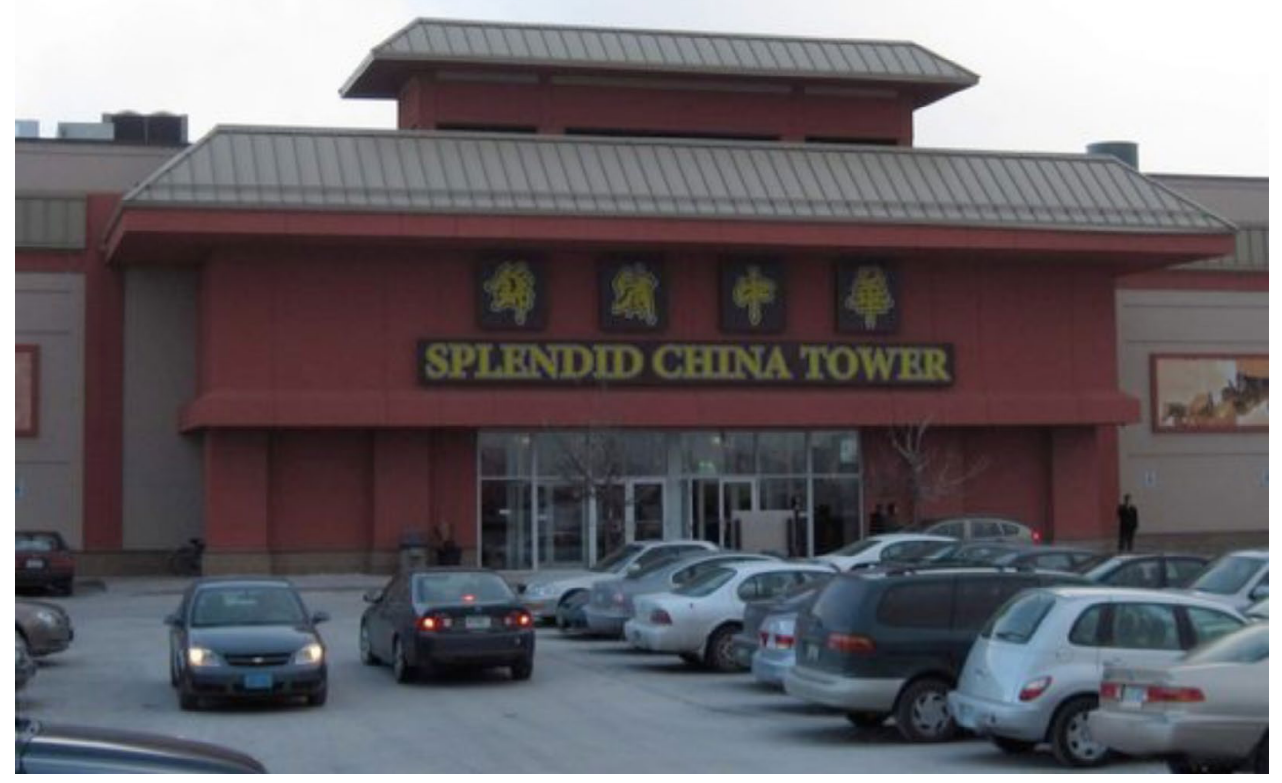

Figure 7. The Splendid China Tower converted from a former Canadian Tire store.

Table 3: Profiles of the Three Malls and Proposed New Retail Space

GFA $=$ Gross Floor Area, FAR $=$ Floor Area Ratio

Source: City of Toronto 2007, CSCA 2010, Heaslip 2011

\begin{tabular}{|l|l|l|l|l|l|l|}
\hline Ethnic Mall & $\begin{array}{l}\text { Current Store \# } \\
\text { (excl. vacancy) }\end{array}$ & $\begin{array}{c}\text { Current } \\
\text { GFA (sq.ft) }\end{array}$ & $\begin{array}{l}\text { Proposed } \\
\text { GFA } \\
\text { (sq.ft) }\end{array}$ & $\begin{array}{c}\text { Total GFA } \\
\text { (sq.ft) }\end{array}$ & $\begin{array}{c}\text { Projected } \\
\text { FAR }\end{array}$ & Tenure \\
\hline Pacific Mall & $\begin{array}{l}359 \\
\text { Food-related (14.2\%) } \\
\text { Other Retail (66.3\%) } \\
\text { Other Services } \\
(19.5 \%)\end{array}$ & 276,000 & 375,000 & 651,000 & 1.1 & condominium \\
\hline $\begin{array}{l}\text { Market } \\
\text { Village/ } \\
\text { Cemington } \\
\text { Centre }\end{array}$ & $\begin{array}{l}\text { food-related (35.7\%) } \\
\text { Other Retail (35.3\%) } \\
\text { Other Services } \\
(28.9 \%)\end{array}$ & 352,000 & 856,000 & 856,000 & 0.85 & $\begin{array}{l}\text { leasehold; to } \\
\text { be changed to } \\
\text { condominium }\end{array}$ \\
\hline $\begin{array}{l}\text { Splendid } \\
\text { China } \\
\text { Tower }\end{array}$ & $\begin{array}{l}\text { 152 } \\
\text { Food-related (11.8\%) } \\
\text { Other Retail (36.8\%) } \\
\text { Other Services } \\
(51.3 \%)\end{array}$ & 90,000 & 247,000 & 337,000 & 1.3 & condominium \\
\hline
\end{tabular}


These three malls currently provide over 700,000 square feet of retail space that is mainly occupied by Chinese owned/operated businesses (Table 3). Without the readapted uses of these retail facilities by Chinese businesses, the area would likely have suffered from business blight. The Chinese businesses have succeeded and retrofitted the retail facilities, contributing to the revitalization of the local neighbourhood and economy. Additionally, these Chinese malls are providing community spaces to serve various community functions. Community life is observed alongside business functions in these Chinese malls, as described below.

\section{Current Business and Community Functions in the Three Chinese Malls}

Lung-Amam (2015a) studied Asian malls in Silicon Valley, and concluded that these malls play an important role in everyday life for suburban Asian-Americans, serving as spaces that provide comfort and acceptance, reinforce culture and identity, and promote socialization and community-building. Similarly, the Chinese malls in our study are not only shopping destinations for cultural goods and services, but also important community spaces for the Chinese community and the community at large. A discussion of how these Chinese businesses function and serve community life in the malls will help explain their role in retrofitting the existing neighbourhood.

Businesses in the three malls have developed different specialties, serving Chinese and non-Chinese people who live near the malls and across the GTA (Table 3). In Pacific Mall, retail is the most prominent component, representing 66.3\% of businesses: mainly Asian-style apparel, gifts, jewelry, and electronic products, especially for trend-setting youth. The predominance of retail is partially due to the small store size (ranging from 145 to 1200 square feet, with an average of 200 square feet) that may not be suitable for other types of businesses. Its highly concentrated retail activities and its diverse Asian goods serve a strong regional market demand and attract tourists. In fact, the Pacific Mall is an official tourist designation recognized by York Region, the regional government of Markham, which means it remains open even on statutory holidays. Its second floor Heritage Town showcases pieces of Chinese art and architecture and provides a popular Asian food court as the major attraction for tourists (Figure 8) (Zhuang 2015). 
The service sector in the mall features Asian-style karaoke bars, video game arcades, banks, hair salons, clinics and pharmacies, travel agencies, and optical stores.

Figure 8. A Glimpse of the interiors of the malls (top: Heritage Town in Pacific Mall; bottom: food court in Market Village).
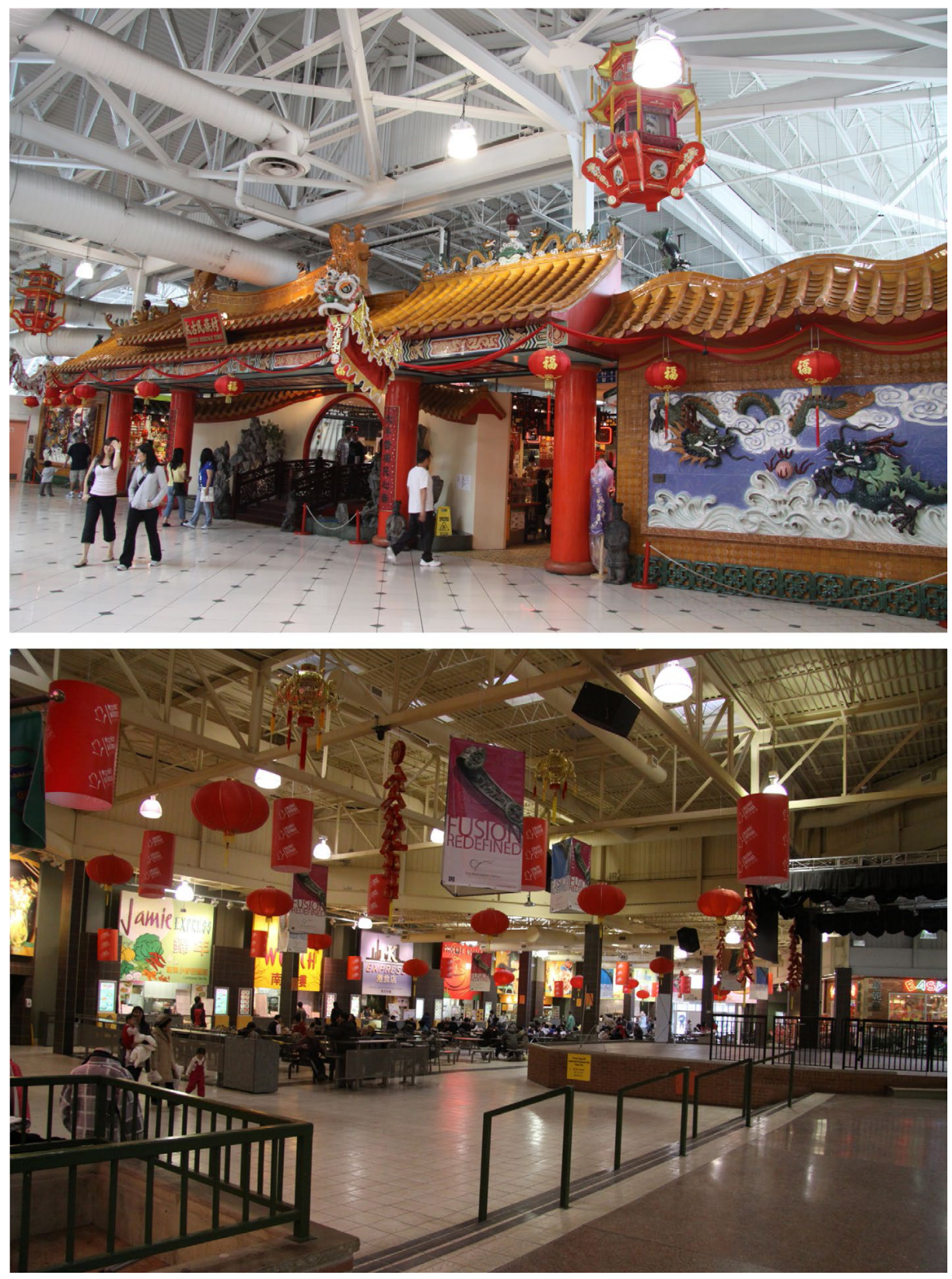
Market Village is under a leasehold program, which means the developer controls the tenant mix. It has similar ratios of businesses in all three categories: food-related: $35.7 \%$; other retail: $35.3 \%$; and other services $28.9 \%$. Its food court provides a variety of Asian cuisine, with restaurants and grocery stores selling Asian produce and goods as anchors for family-oriented activities. A stage near the food court is used to host weekly cultural and community events (Figure 8). Retailers sell apparel and household products, and the service sector provides banking, personal health, and beauty services, among others, and includes a Chinese Cultural Centre, Chinese Senior Association, and extracurricular learning centres for school-age children. In contrast to the other two malls, Splendid China Tower features more personal and professional services $(51.3 \%)$, such as health clinics, hair and beauty salons, and offices for law, immigration, accounting, educational training, real estate, and travel. Its two-storey lobby is the central area for commercial and community events. The three malls complement each other, serving the needs of both local and region-wide Chinese and non-Chinese communities.

Of the 49 shoppers surveyed in Market Village and Pacific Mall, 65\% were locals from Markham or Scarborough (a nearby suburb), while the rest were regional customers mainly from other areas of the GTA. Visitors came to shop (71\%), eat (8\%), meet friends and family (8\%), obtain personal services (8\%), or do other things in the malls; on average, they visited the mall 2.5 times per month (Table 4). Estimates from 148 business owners and operators (70\% in retail and $30 \%$ in service) suggest that $25 \%$ of their customers are of non-Chinese origin, indicating that these Chinese enterprises serve the needs of the wider community. One interviewed planner commented on the mixed clientele when being asked who these malls should target:

I don't think we should target certain group. Like Pacific Mall, it's not like all the Chinese go there; there're non-Chinese, 'cause when they come in they want to see how Pacific Mall looks like, especially the ones [who] haven't been to China or Hong Kong.

These Chinese malls and conventional malls differ dramatically in how customers get to, and use, them. Visitors to Chinese malls tend to walk, bike, or take public transit, due to their proximity to adjacent residential neighbourhoods and to bus and commuter train stations. They 
also tend to stay longer, for shopping, dining, entertainment, social activities, and accessing services. Thus Chinese malls serve as significant community centres. One developer noted the differences: "there's [transit] infrastructure and foot traffic [in this area]. Infrastructure influences foot traffic. There are also residents' habits." One interviewed architect was amazed by the variety of community functions and services Chinese malls provide and how they "[act] more like a community centre in a lot of ways." He further commented:

If I say [to my friends] "let's go to dinner in a shopping mall," they'd look at me as if I were crazy. The reality is some of the better Chinese restaurants certainly have been in shopping malls in the city.

Planners are aware of the effects of Chinese malls on the larger community; one planner commented on their tourist potential:

We want that area to become one of the pictures in tourist guides of Toronto and be one of the top 10 attractions ... People use [the Chinese malls] more like they use Disney World, [chuckles] than a shopping centre ... where you do more conventional shopping. It's a place you should go, to visit and shop. Very different from just a place you need to go, just to buy some clothes.

According to interviewed officials, these Chinese malls as tourist attractions create not only economic opportunities, but also a means to enhance cultural identity and promote intercultural exchange. It has positive social and cultural impacts on the existing community.

Our findings from the business surveys reflect a healthy and stable business environment in the malls that attracts Chinese entrepreneurs to invest and build their enterprises. Most of the business owners in Market Village (100\%) and Pacific Mall (86\%) who completed the business survey had never moved their businesses, whereas half of the surveyed businesses in the Splendid China Tower had moved from other locations. On average, business owners in Market Village, Pacific Mall, and Splendid China Tower had been operating for 15, 4, and 2 years, respectively (Table 4). Data from 2000 to 2010 indicate that the vacancy rates in Market Village 
and Pacific Mall (2.5\% and 2.6\% respectively) have been much lower than in other community shopping centres (8.3\%) in the City of Toronto (CSCA 2010). Splendid China Tower has a much higher vacancy rate $(22.1 \%)$, most likely because it is still in the early stages of attracting businesses.

The factors attracting businesses vary between malls. "Traffic of customers" was a significant factor for $86 \%$ of merchants in Pacific Mall and $70 \%$ of those in Market Village. In Splendid China Tower, "reasonable rent" was the most important factor for $73 \%$ of merchants, followed by "good business environment" (36.4\%) and "public transit" (31.8\%). For merchants in Pacific Mall, other reasons considered significant included "public transit" (54\%) and "tourist attraction" (54\%); for merchants in Market Village, reasons included "good business environment" (60\%), "proximity to Chinese community" (50\%), "concentration of Chinese businesses" (50\%), and "reasonable rent" (50\%).

One of the important components of the business survey is to understand the effects of business concentration on the community. Overall, surveyed merchants considered the concentration of Chinese businesses in the area to be beneficial, stating that it serves the needs of the Chinese community (79.8\%), provides employment opportunities for Chinese immigrants $(68.2 \%)$, makes an economic contribution to the society at large $(69.5 \%)$, and does not hinder immigrants' social integration (41.6\%). The data suggest that from merchants' perspectives, these Chinese malls provide vital spaces to support immigrants' economic and community activities. Unlike traditional Chinese business enclaves, these malls are also well connected to the wider community, socially and economically, which helps Chinese immigrants better integrate into the society at large. When it comes to future redevelopment of the malls, $40.7 \%$ of the merchants believed it would be beneficial to their business, and 26.2\% disagreed. Shoppers were more positive than merchants, with $50.9 \%$ of them being optimistic and hoping more convenience and stores would be brought into the area (Table 4).

Table 4. Summary of business and shopper survey findings. 
Business Surveys (154)

Business Operation

Business Types

Retail: 107 (apparel 21\%; giftshop 19\%; household appliances $13 \%$ );

Service; 45 (food services 31\%; health clinics 16\%, hair and beauty $13 \%$ )

Business owners/operators

Business owners: 71 (46\%); 20 (13\%) out of the 71 business owners are also property owners

Business operators: 83 (54\%)

Place of origin: $92 \%$ immigrants (49\% from $\mathrm{HK}, 42 \%$ from Mainland China, $9 \%$ from others)

Average business operation time in the MV: 15 years; PM: 4 years; SCT: 2 years mall

\section{Average number of employees \\ $\%$ of customers of Chinese origin \\ $\%$ of customers come from}

\section{5 persons}

$75 \%$

Markham: 35.5\%; Scarborough:36.4\%; rest of the GTA: $17 \%$; rest of Canada: $7 \%$; outside Canada: $4 \%$

MV: $100 \%$ never moved; PM: $86 \%$ never moved; SCT: 50\% moved from elsewhere

MV: traffic of customers (70\%); good business environment $(60 \%)$; proximity to Chinese community (50\%); concentration of Chinese businesses (50\%); reasonable rent $(50 \%)$

PM: traffic of customers (86\%); public transit (54\%); tourist attraction (54\%)

SCT: reasonable rent (73\%); good business environment (36.4\%); public transit (31.8\%)

Ideal business environment to run business

Condominium Chinese mall: $41.8 \%$; Conventional shopping mall: $34.3 \%$; Leasehold Chinese mall: $16.4 \%$; storefronts on main street: $4.5 \%$; others: $3 \%$

Views on Current Business Environment and Future Mall Redevelopment 
Concentration of Chinese businesses

Major concerns about running business in the mall

Benefits of future mall redevelopment

Other beneficial factors

Future mall redevelopment will cause

Shopper Intercept Surveys (49)
Serves the needs of the Chinese community:

Agree (79.8\%); Neutral (15.7\%); Disagree (4.6\%)

Provides employment opportunities for Chinese immigrants:

Agree (68.2\%); Neutral (21.9\%); Disagree (10.0\%)

Makes an economic contribution to the society at large: Agree (69.5\%); Neutral (23.2\%); Disagree (7.3\%)

Does not hinder immigrants' social integration: Agree (41.6\%); Neutral (26.8\%); Disagree (31.5\%)

Lack of parking: $53 \%$; Rent too high: $51 \%$; Traffic congestion: $43 \%$; Store competition: $36 \%$

Will be beneficial to individual business:

Agree (40.7\%); Neutral (33.1\%); Disagree (26.2\%)

Will increase business property value:

Agree (62.7\%); Neutral (26.0\%); Disagree (11.3\%)

"Chinese theme" attracts more customers to the mall: Agree (64.1\%); Neutral (6.1\%); Disagree (9.8\%)

Canada's new Approved Destination Status with China brings more Chinese tourists to the GTA, thus benefits individual business:

Agree (53.6\%); Neutral (27.8\%); Disagree (18.5\%)

More business competition:

Agree (75.0\%); Neutral (16.4\%); Disagree (8.6\%)

Market over-saturation:

Agree (72.5\%); Neutral (18.8\%); Disagree (8.7\%)

Traffic congestion:

Agree (76.0\%); Neutral (19.3\%); Disagree (4.7\%)

Lack of parking space:

Agree (78.0\%); Neutral (14.7\%); Disagree (7.3\%)

Increased rent price:

Agree (66.0\%); Neutral (24.0\%); Disagree (10.0\%) 


\begin{tabular}{|c|c|}
\hline Shoppers' demographic profiles & $\begin{array}{l}\text { Gender: Male (67\%); Female (33\%) } \\
\text { Age: } 18-20 \text { yrs (6\%); } 21-30 \text { yrs (27\%); } 31-40 \text { yrs } \\
(29 \%) ; 41-50 \text { yrs (16\%); } 51-60 \text { yrs (14\%); } 61-70 \text { yrs } \\
(4 \%) ; 71 \text { yrs and up (4\%) } \\
\text { Ethnic origin: Cantonese (57\%); Mandarin (24\%); Eastern } \\
\text { Asian (12\%); Vietnamese (2\%); South Asian (2\%); } \\
\text { Caucasian (2\%) }\end{array}$ \\
\hline Where shoppers come from & $\begin{array}{l}\text { Scarborough ( } 43 \%) \text {; Markham (22\%); rest of the GTA (32\%); } \\
\text { outside Canada ( } 2 \%)\end{array}$ \\
\hline Purpose of the trip & $\begin{array}{l}\text { Shopping: } 71 \% \text {; Dining: } 8 \% \text {; Meet friends and family: } 8 \% \text {; } \\
\text { Personal services: } 8 \%\end{array}$ \\
\hline Frequency of visiting the mall & $\begin{array}{l}\text { More than once a week: } 8.9 \% \text {; Once a week: } 22.2 \% \text {; Once a } \\
\text { month: } 26.7 \% \text {; Twice a month: } 33.3 \% \text {; Once every two } \\
\text { months: } 6.7 \% \text {; Twice a year: } 2.2 \%\end{array}$ \\
\hline What shoppers like the most of the mall & $\begin{array}{l}\text { Variety of stores: } 21.3 \% \text {; Food: } 14.9 \% \text {; Reasonable price: } \\
\text { 10.6\%; Proximity to home: } 6.4 \% \text {; Neutral: } 36.2 \%\end{array}$ \\
\hline $\begin{array}{l}\text { What shoppers dislike the most of the } \\
\text { mall }\end{array}$ & $\begin{array}{l}\text { Crowdedness: } 16.7 \% \text {; Parking: } 4.2 \% \text {; Traffic congestion: } \\
\text { 4.2\%; Restroom condition: } 4.2 \% \text {; Neutral: } 58.3 \%\end{array}$ \\
\hline Views on future mall redevelopment & $\begin{array}{l}\text { Optimistic: } 47.9 \% \text {; Neutral: } 22.9 \% \text {; Concerns for parking: } \\
6.3 \% \text {; Concerns for traffic congestion: } 6.3 \%\end{array}$ \\
\hline
\end{tabular}

\section{Future Redevelopment and Retrofitting}

Although the three malls have played a role in readapting the retail landscape and revitalizing the local neighbourhood and economy, their built form and land use (i.e., singular retail use and large parking lots) do not differ substantially from mainstream suburban big-box stores, which are often criticized as unsustainable spaces and have been the subject of suburban retrofitting projects. Privately owned, car-oriented shopping malls generally lack walkable and accessible public space to connect with the surrounding area, which can make these concentrated ethnic business centres more detached or isolated from the rest of the neighbourhood. These factors can hinder the potential of turning an ethnic retail space into a more accessible, integrated, and inclusive community space. A sprawling form of ethnic retailing (e.g., low density, singular use) may also affect its competitiveness versus a more compact, mixed-use, and human-scaled retail format. It is imperative to consider how to regenerate these ethnic retail spaces so that they not 
only maximize their contributions as a central business and community space, but also integrate with existing neighbourhoods in a more sustainable and inclusive way. As described below, each mall is currently slated for redevelopment, making it critical to examine how their transformation plans may help or hinder future retrofitting. The discussion here will also help answer the research questions: What are the redevelopment approaches that would better meet current retrofitting principles? Who are the key players and what are their roles in the retail retrofitting process?

Two decades after Market Village was built, its developer (Remington Group) proposed demolishing the existing mall to make way for a mega-scaled retail complex with a larger footprint, mixed commercial and residential uses, higher density, and better quality of public space, to be known as the "Remington Centre" (Figure 9). Pacific Mall's developer has also proposed expanding the current mall by adding more retail spaces on higher storeys and possibly a hotel. On the Toronto side, Splendid China Tower has proposed a Phase II addition of retail spaces and possibly residential and hotel uses. If built, another nearly two million square feet of retail space will be added (Table 3), targeting entrepreneurs and investors of Asian and Chinese origin, although developers have emphasized that their intensions are, in the words of one: to build "an international mall, not a Chinese mall." Interestingly, none of the developers are of Chinese heritage: they were simply profit driven and willing to take risks.

Figure 9. An architectural model of Remington Centre is being displayed inside Market Village.

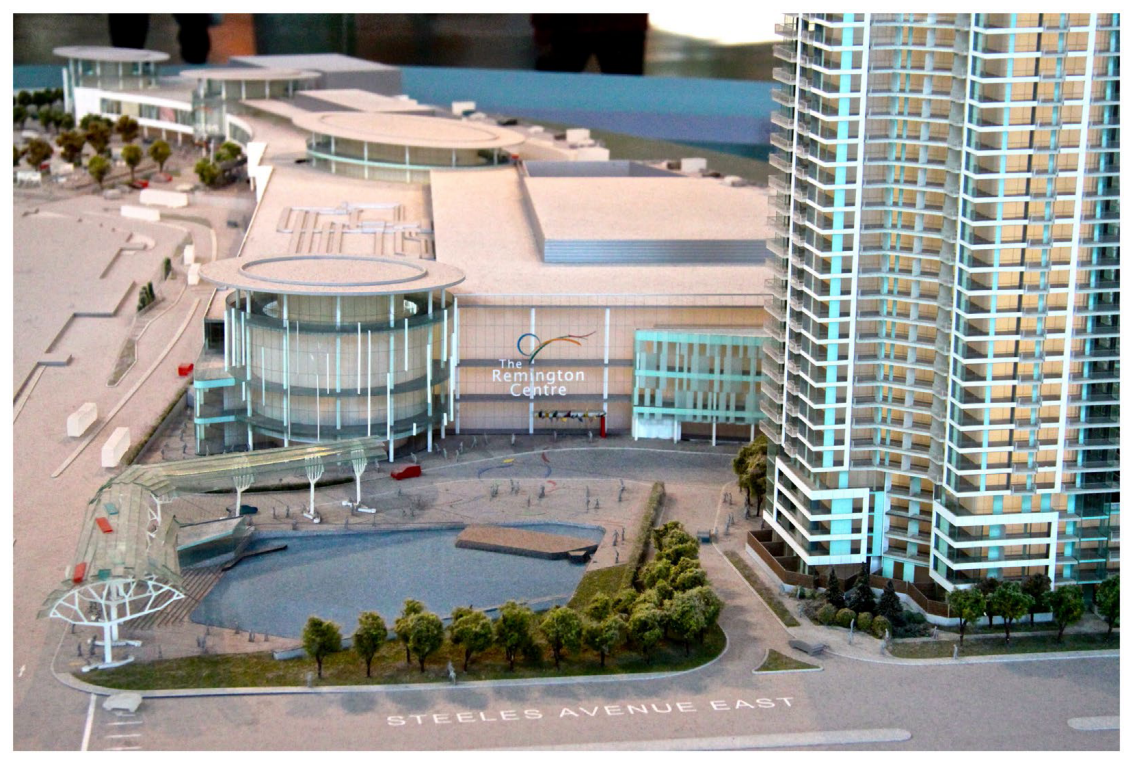


Mega-scaled ethnic retail development is a market-led phenomenon, in which developers are seizing the opportunity to exploit the ethnic market potential. But redevelopment provides opportunities beyond profit if all parties can work together. Among the three redevelopment proposals, the Remington Centre proposal is a good example of how developers, planners, architects, and other municipal stakeholders can explore ways to use ethnic retail places as an anchor, an activity node, and a catalyst to retrofit unsustainable suburban retail spaces. The following sections will mainly focus on its design concepts. The Remington Centre proposal is consistent with Talen's (2011) guiding principles of sustainable urban form-walkability, compactness, and mixed use - in that it will serve, not only as a retail facility, but also as a community centre that is accessible by active transportation (walking, cycling), is connected with mass public transit, encourages higher density and mixed uses, is diverse in terms of uses, built forms, and ethno-cultural backgrounds of users, and is identifiable as a community focal point. The design focus is to turn the new retail facility into a "people place," according to the interviewed architect and planners.

Interviews with a transportation planner and an architect retained by the Remington Centre developers helped clarify various aspects of this approach to urbanism. First, to improve accessibility for pedestrians, cyclists, and transit users, the Remington Centre site will have graded, separate entrances for automobiles to enter a multi-level parking structure. The transportation planner commented, "Everybody is accommodated, but they are accommodated in ... 'separate layers,' which unlocks a lot of the key and important livability aspects for the site." Second, once the surface area is free of automobiles, a large central plaza at the front will help provide pedestrian-friendly public space: the plaza will include seating areas and a reflecting pond that can be turned into a skating rink in the winter (Figure 10). Third, to improve connectivity, the site will be treated as a transit hub, by directly connecting local and regional bus lines and regional commuter train services at the door: According to the transportation planner, "You want more people closer to transit but the reality is, you have to have more people closer to more transit." Fourth, the goal is to encourage higher density and mixed uses: "Doing the retail commercial format in association with the condominium and hotel is, from a traffic perspective, a good thing," as the transportation planner noted. Fifth, identifiable architecture should be used 
in the design of the new mall. The transportation planner and the architect agreed that the site's architecture needs strong, identifiable elements for it to act as the gateway to Markham, but that it should be consistent with the urban design principles of the City of Markham. The proposed architectural design is modern and clean, incorporating various cultural motifs that carry subtle meanings of good luck and good fortune in the Chinese culture, such as the use of water and the round shape of the pond at the front, the site plan in a shape of Ru-Yi (jade), and a pedestrian glass-roofed walkway through the front door that is intended to resemble a school of fish. These components were designed based on the advice from a Chinese Feng Shui master, with the goal of incorporating aspects of Chinese culture and appealing to Chinese investors.

The City of Markham endorsed the urbanism approach in the Remington Centre proposal since they were compatible with the city's urban growth agenda. Asked for his professional viewpoint of the future developments, one Markham city planner commented:

We are really pleased to see it. It is something very unusual ... These [new] developments are very unique. We want the building to have an urban relationship to the street. And we obviously want [it to be] pedestrian friendly; we want connectivity ... Markham has a very strong architectural focus. We are obviously looking to become more urban. Our council has taken a very brave move - to, not expand our world to a great degree - but to focus our growth in intensification. That means that we are becoming much more urban, really quickly. And I think you'll see what's happening in Markham now, is all built-to-the-street, mixed use. We want to see mixed use, we want to see underground parking and we are trying to stitch together real communities.

The City of Markham has been keen to promote sustainable development as evidenced in its strong commitment to building new urbanist neighbourhoods in the past two decades (Grant 2006). There is a good understanding of the Chinese mall phenomenon and the importance of using the proposed mixed-use and higher-density expansion as a major anchor for the local economy and a catalyst to retrofit the area. It is also acknowledged that many individuals from the Asian community are used to high density and mixed-use spaces due to their previous urban 
living experiences. The interviewed city planner elaborated how this understanding has come a long way when being asked about the potential impacts of the future development:

It makes sense. I think we are understanding that residential is a natural fit with retail ... If someone here told the planner 15 years ago that somebody would live in apartment on top of a shopping centre, he'd be like "you gotta be kidding." And now we realize that there is a different market up there and the market really wants to be [like that].

City officials from both Markham and Toronto agreed that future development of the area is up to the private development industry and the market to decide because "there's no point in municipality pushing that if we don't have the land owners on side" (Markham planner). While developers are leading the redevelopment, the Remington Centre proposal is still under scrutiny by municipal professionals and other stakeholders, who are evaluating its relationship with the other two Chinese malls and its possible effects on the existing neighbourhood. Additionally, because the site of the three malls is located at the intersection of two municipalities, the proposed retrofitting is particularly complex, involving local, regional, and provincial governments, as well as their affiliated agencies, such as the City of Toronto, the City of Markham, the Regional Municipality of York, Toronto Transit Commission, Metrolinx (a regional transportation authority), GO Transit (regional transit system), and York Region Transit. It will not be easy for all of these stakeholders to reach consensus, but interviews with two councillors, three planners, and one architect revealed that active dialogue was taking place among the different parties. The transportation planner retained by both Remington and Pacific Mall developers has been a key player, convincing all parties to work together to address issues related to parking and traffic and encourage sustainable urbanism.

Traffic, parking, and congestion have been major concerns to both municipalities, merchants, and the local community given that the area has been developed as the epicentre of Chinese businesses (Zhuang 2013). In this study, nearly 50\% of business survey respondents considered "parking" and "traffic congestion" the biggest issues when running their business in the three malls, and over $75 \%$ were concerned about these issues as negative consequences of the 
future redevelopment. All eight interviewed professionals agreed that with increased density, the development of the new malls will undoubtedly bring challenges to the area in terms of parking, traffic congestion, and site access. A "steering committee" with representatives from the abovementioned public agencies was organized to address the traffic issues. Additionally, Toronto's planners have exercised Section 37 of Ontario's Planning Act: they have negotiated with the Splendid China Tower developer, who has agreed to pay for road extension and the expansion of a nearby community centre in exchange for the higher density in their development proposal. As a result, the ethnic mall development will also benefit the larger community.

Despite the challenges, city planners are more prepared today for the future retrofitting of these Chinese malls and the surrounding area, because they have a better understanding of the changing demographics and the diverse needs of the community. When Pacific Mall was first proposed in the 1990s, the planners had little knowledge about condominium-style Chinese malls and were inexperienced in dealing with ethnic communities: they really only played a reactive role, responding to technical issues, such as parking and traffic (Zhuang 2013). Two decades later, one planner who was involved in the original development of Pacific Mall noted that:

We are becoming much more mature, as a community. You know, we've learned a lot. So I think we were more challenged than we are now ... If [what's proposed now] had been proposed in the 1990s ... [we] wouldn't have known what to do. Now [we] look at that kind of density and scale, and very modern and very urban stuff, no problem! Conceptually [we] are onboard, and conceptually the community is onboard as well. We are not getting the fundamental "stop, stop, stop!' In the '90s, that's what we would get from the community, which would just be like, "whoa stop! Let me off!” We don't get that anymore. So I think we are a lot less challenged than we were then, because we have grown into a much more urban-looking place.

The Markham planner commented that Markham's municipal agenda includes “being inclusive and being urban." Within this political climate, both municipalities are receptive to the redevelopment proposals and, as reported by interviewees, the three proposals have faced little 
objection from local constituents. Decision-makers and planning professionals should continue to explore these opportunities carefully: open-minded and creative approaches will not only integrate ethnic retailing into the existing urban fabric, but also use it as a catalyst for retrofitting suburbia.

\section{Conclusion}

In this paper we traced how once-declining suburban retail spaces were readapted and retrofitted by Chinese businesses since the 1990s. In an ethnoburb, the concentration of ethnic businesses generates a critical mass for economic activities, social services, and community life, which significantly distinguish these retail places from conventional suburban shopping centres. Yet, they still require better integration with surrounding neighbourhoods and connections with other community functions, such as housing, transit, and public space. The Chinese malls we studied have the potential to meet most of the criteria suggested by Talen (2010) as a guide to choosing sites for retrofitting: they feature connectivity, density, diversity, and good transit infrastructure. Since the malls are excellent candidates for further retrofitting, the plans for their redevelopment are important. Our discussion of the redevelopment proposals and their approach to sustainable urbanism suggests that a second wave of retrofitting could be on its way.

It is important to note that there is no one-size-fits-all approach when it comes to retrofitting suburbia. The Chinese mall cases presented here demonstrate a two-step process of retrofitting, with the initial stage of development being driven by market forces and the proposed redevelopment involving various stakeholders and municipal interventions. Developers built ethnic malls because it is profitable; yet leaving the malls' long-term sustainability to the market is risky, and municipal intervention is required. Over the past two decades, city planners have developed a much better understanding of the Chinese mall phenomenon and its impacts on the community. They have also learned lessons about how to make these suburban Chinese retail places more walkable, better connected to housing, transit and services, and eventually, more sustainable. 
Although planners continue to play a reactive role and municipal bureaucracy does exist, as demonstrated in the case studies, planners can still use effective planning tools, such as secondary plans to provide intensified mixed-uses, public transit, and pedestrian-scaled public spaces as desirable add-on features to enhance the commercial and community functions of ethnic retail areas. Special area studies and community improvement plans are also possible planning interventions. While there is no prescribed formula for retrofitting suburbia, ethnic retail forms allow opportunities to recreate community spaces and regenerate suburban neighbourhoods. For the long-term sustainability of the community as a whole, municipalities should continue to promote greater social inclusivity and integration in ethnic retail places, such as encouraging privately-owned public spaces for community functions and purposes. After all, retrofitting suburbia is more than a matter of physical repair; rather, building a welcoming and inclusive community space is the key to long-term sustainability.

\section{References}

Borjas, G. 1997. To Ghetto or not to Ghetto: Ethnicity and Residential Segregation. Cambridge, MA: National Bureau of Economic Research.

Breton, R. 1964. "Institutional Completeness of Ethnic Communities and the Personal Relations of Immigrants.” The American Journal of Sociology 70 (2): 193-205.

Chen, C. 2005. “Constructing Pacific Mall.” Journal for the Arts, Sciences, and Technology 3(1): 89-100.

City of Toronto. 2007. "Staff Report: 4675 Steeles Avenue East (Splendid China Square Inc.) Zoning Application - Status Report.” City of Toronto, Canada. Accessed December 10, 2011. http:// www.toronto.ca/legdocs/mmis/2007/sc/bgrd/backgroundfile-4717.pdf. 
Centre for the Study of Commercial Activity (CSCA). 2010. Annual Business Survey 20002010. Toronto: Ryerson University.

Collins, J. 2015. "The Political Economy of the Social Transformation of Australian Suburbs." In Social Transformation and Migration: National and Local Experiences in South Korea, Turkey, Mexico and Australia, edited by S. Castles, D. Ozkul and M. Cubas, 255-268. New York: Palgrave Macmillan.

Dunham-Jones, E. and J. Williamson. 2011. Retrofitting Suburbia: Urban Design Solutions for Redesigning Suburbs. Updated Edition. Hoboken, NJ: John Wiley \& Sons.

Edgington, D., M. Goldberg, T. and Hutton. 2006. Hong Kong Business, Money, and Migration in Vancouver. In From Urban Enclave to Ethnic Suburb: New Asian Communities in Pacific Rim Countries edited by W. , 155-183. Honolulu: University of Hawaii Press.

Fong, T. 1994. The First Suburban Chinatown: The Remaking of Monterey Park, California. Philadelphia: Temple University Press.

Gillmor, D. 1998. "Satellite City: We Have Seen the Future at the Pacific Mall: Placenta Tablets, Crocodile Bile and Gold Card-toting Teenagers.” Toronto Life 32(17):146.

Government of Canada. 2015a. "Apply to Immigrate to Canada." Government of Canada. Accessed May 19, 2015. http://www.cic.gc.ca/english/immigrate/apply.asp.

Government of Canada. 2015b. Employment Equity Act. Government of Canada. Accessed May 19, 2015. http://laws-lois.justice.gc.ca/PDF/E-5.401.pdf. 
Grant, J. 2006. Planning the Good Community: New Urbanism in Theory and Practice. Abingdon: Routledge.

Harwood, S. A. 2005. "Struggling to Embrace Difference in Land-Use Decision Making in Multicultural Communities.” Planning, Practice \& Research 20(4): 355-371.

Heaslip, S. 2011. "Preliminary Recommendation Report: The Remington Group (Market Village Markham) and Pacific Mall North East Kennedy Road and Steeles Avenue East Applications for Site Plan Approval for Two Proposed Commercial Developments." Report of June 21 to Development Services Committee. City of Markham.

Lai, D. C. 2000. "The Impact of New Immigration Policies on the Development of New Chinatowns and New Chinese Shopping Plazas in Canada." Asian Profile 28(2): 99-116.

Lai, D. C. 2001. A Study of Asian-themed Malls in the Aberdeen District of City of Richmond, British Columbia. Vancouver, Canada: Vancouver Centre of Excellence for Research on Immigration and Integration in the Metropolis.

Li, W. 1998a. "Anatomy of a New Ethnic Settlement: The Chinese Ethnoburb in Los Angeles." Urban Studies 35(3): 479-501.

Li, W. 1998b. "Los Angeles's Chinese Ethnoburb: From Ethnic Service Center to Global Economy Outpost." Urban Geography 19(6): 502-517.

Li, W. 2005. "Beyond Chinatown, Beyond Enclave: Reconceptualizing Contemporary Chinese Settlement in the United States." GeoJournal 64: 31-40. 
Li, W. 2006. "Introduction: Asian Immigration and Community in the Pacific Rim.” In From Urban Enclave to Ethnic Suburb: New Asian Communities in Pacific Rim Countries, edited by W. Li, 1-22. Honolulu: University of Hawaii Press.

Li, W. 2009. Ethnoburb: The New Ethnic Community in Urban America. Honolulu: University of Hawaii Press.

Lo, L. 2006. "Suburban Housing and Indoor Shopping: The Production of the Contemporary Chinese Landscape in Toronto.” In From Urban Enclave to Ethnic Suburb: New Asian Communities in Pacific Rim Countries, edited by W. Li, 134-154. Honolulu: University of Hawaii Press.

Lo, L. and S. Wang. 1997. “Settlement Patterns of Toronto’s Chinese Immigrants: Convergence or Divergence?” Canadian Journal of Regional Science 20: 49-72.

Luk, C. M. 2005. "Contextualizing the Emergence of New Chinatowns: An Introduction.” GeoJournal 64: 1-6.

Luk, C. M. and Mai B. Phan. 2005. "Ethnic Enclave Reconfiguration: A 'New' Chinatown in the Making.” GeoJournal 64: 17-30.

Lukez, P. 2007. Suburban Transformations. New York: Princeton Architectural Press.

Lung-Amam, W. 2015a. The Vibrant Life of Asian Malls in Silicon Valley. In Making Suburbia: New Histories of Everyday America. edited by J. Archer, P. J. P. Sandul and K. Solomonson, 208-226. Minneapolis: University of Minnesota Press.

Lung-Amam, W. 2015b. "Malls of Meaning: Building Asian America in Silicon Valley Suburbia.” Journal of American Ethnic History 34(2): 18-53. 
Parlette, V. and D. Cowen. 2011. "Dead Malls: Suburban Activism, Local Spaces, Global Logistics.” International Journal of Urban and Regional Research 35(4): 794-811.

Preston, V. and L. Lo. 2000. “Asian Theme Malls in Suburban Toronto: Land Use Conflict in Richmond Hill.” Canadian Geographer 44(2): 182-190.

Qadeer, M. A. 1997. "Pluralistic Planning for Multicultural Cities." Journal of the American Planning Association 63(4): 481-494.

Qadeer, M. A. 1998. "Ethnic Malls and Plazas: Chinese Commercial Developments in Scarborough, Ontario." Working Paper. Toronto: Joint Centre of Excellence for Research on Immigration and Settlement (CERIS).

Qadeer, M. A. 2003. "Ethnic Segregation in Toronto and the New Multiculturalism.” Research Bulletin \#12. Toronto: Centre for Urban and Community Studies.

Qadeer, M. A., S. K. Agrawal and A. Lovell. 2010. "Evolution of Ethnic Enclaves in the Toronto Metropolitan Area, 2001-2006.” International Migration and Integration 11:315-339.

Relph, E. 2014. Toronto: Transformations in a City and its Region. Philadelphia: University of Pennsylvania Press.

Statistics Canada. 2011. 2011 National Household Survey (NHS) Profiles Files/Profile of Census Tracts. Statistics Canada. Accessed August 15, 2015. http://

dc1.chass.utoronto.ca.ezproxy.lib.ryerson.ca/cgi-bin/census/2011nhs/displayCensus.cgi? year $=2011 \&$ geo $=$ ct. 
Statistics Canada. 2013a. Ethnic Origin Reference Guide. Accessed April 10. 2015. http:// www12.statcan.gc.ca/nhs-enm/2011/ref/guides/99-010-x/99-010-x2011006-eng.cfm.

Statistics Canada. 2013b. Home Language. Accessed April 10, 2015. http://www12.statcan.gc.ca/ nhs-enm/2011/ref/dict/pop042-eng.cfm.

Statistics Canada. 2015. Visible Minority of Person. Accessed April 10, 2015. http:// www.statcan.gc.ca/concepts/definitions/minority-minorite1-eng.htm.

Talen, E. 2010. "Fixing the Mess We Made." Planning 76(9): 32-36.

Talen, E. 2011. "Sprawl Retrofit: Sustainable urban Form in Unsustainable Places." Environment and Planning B: Planning and Design 38(6): 952-978.

Talen, E., ed. 2015. Retrofitting Sprawl: Addressing Seventy Years of Failed Urban Forms. Athens: University of Georgia Press.

Wang, S. 1999. "Chinese Commercial Activity in the Toronto CMA: New Development Patterns and Impacts." Canadian Geographer 43(1): 19-35.

Wang, S. and J. Zhong. 2013. "Delineating Ethnoburbs in Metropolitan Toronto.” Working Paper No. 100. Toronto: CERIS.

Williamson, J. 2013. Designing Suburban Futures: New Models from Build a Better Burb. Washington, DC: Island Press.

Wong, T. 2007. "Going to the Wall for the Asian Mega-mall.” Toronto Star, November 17. http:// www.thestar.com/business/2007/11/17 going_to_the_wall_for_the_asian_megamall.html. 
Wood, J. 1997. "Vietnamese American Place Making in Northern Virginia." Geographical Review 87(1): 58-72.

Wood, J. 2006. “Making America at Eden Center.” In From Urban Enclave to Ethnic Suburb: New Asian Communities in Pacific Rim Countries, edited by W. Li, 23-40. Honolulu: University of Hawaii Press.

Xue, J., W. Friesen and D. O'Sullivan. 2012. "Diversity in Chinese Auckland: Hypothesising Multiple Ethnoburbs." Population, Space and Place 18(5): 579-595.

Zhou, M. 2009. Contemporary Chinese America: Immigration, Ethnicity, and Community Transformation. Philadelphia: Temple University Press.

Zhou, M. 2013. "The Transformation of Chinese American Communities: New York vs. Los Angeles." In New York and Los Angeles: The Uncertain Future, edited by D. Halle and A. Beveridge, 358-382. New York: Oxford University Press.

Zhuang, Z. C. 2013. "Rethinking Multicultural Planning: An Empirical Study of Ethnic Retailing." Canadian Journal of Urban Research 22 (2): 90-116.

Zhuang, Z. C. 2015. "Construction and Reconstruction of Ethnicity in Retail Landscapes: Case Studies in the Toronto Area." Journal of Urban Design 20 (5): 677-697.

Zhuang, Z. C. 2016. "Planning for Diversity in a Suburban Retrofit Context: The Case of Ethnic Shopping Malls in the Toronto Area." In Planning Canada: A Case Study Approach, edited by R. Thomas, 134-142. Canada: Oxford University Press. 


\section{Acknowledgments}

We would like to acknowledge the help of the participants in this study who generously contributed their time and shared their perspectives with us. They made this research possible. We are grateful to Wendy Choi who has assisted in the collection of research data. Special thanks go to the anonymous reviewers for their insightful comments. The authors are, of course, solely responsible for the content of this article.

\section{Disclosure statement}

No potential conflict of interest was reported by the authors.

\section{Funding}

This article was completed with financial support from the Faculty of Community Services and the Office of Research Services at Ryerson University, Canada.

\section{Notes on contributors}

Zhixi Cecilia Zhuang is an Associate Professor at the School of Urban and Regional Planning, Ryerson University. Her current research focuses on emerging suburban ethnic retail landscapes and aims to explore place-making practices in ethnic retail neighbourhoods and their implications for municipal planning.

Amanda Xiaoxuan Chen was the Research Assistant of this project and graduated from the Master of Planning programme at Ryerson University's School of Urban and Regional Planning. She is currently working with Hotspex Inc. as a senior research analyst.

\section{Notes}


${ }^{i}$ Breton coined the term "institutional completeness," which refers to the number, size, and variety of institutions that an ethnic community has developed. These institutions may include formal "organizations of various sorts: religious, educational, political, recreational, national, and even professional ... Institutional completeness would be at its extreme whenever the ethnic community could perform all the services required by its members" $(1964,194)$.

ii According to Statistics Canada 2011 National Household Survey, home language refers to "the language spoken most often or on a regular basis at home by the individual" (2013b, par. 2), and ethnic origin refers to "the ethnic or cultural origins of the respondent's ancestors" (2013a, par. 2). Defined by the Employment Equity Act, visible minorities refer to "persons, other than Aboriginal peoples, who are non-Caucasian in race or non-white in colour" (Government of Canada 2015b, 2). Statistics Canada adopts this definition and the Canadian Census currently includes the following visible minority groups: Chinese, South Asian, Black, Arab, West Asian, Filipino, Southeast Asian, Latin American, Japanese, and Korean (Statistics Canada 2015). The classification of visible minority groups is self-reported.

iii In 1978, the Canadian government introduced the immigration category "Business Class Immigrant" with the subgroups of Entrepreneur, Investor, and Self-Employed, in order to attract immigrants with entrepreneurial skills and sufficient financial capital to invest in the local economy and create businesses and jobs. The program is now terminated but similar programs have been developed with different application eligibilities and requirements (Government of Canada 2015a). 